\title{
Study of the aromatic hydrocarbons poisoning of platinum cathodes on proton exchange membrane fuel cell spatial performance using a segmented cell system
}

\author{
Tatyana V. Reshetenko*, Jean St-Pierre \\ ${ }^{a}$ Hawaii Natural Energy Institute, University of Hawaii, Honolulu, HI 96822
}

\begin{abstract}
Aromatic hydrocarbons are produced and used in many industrial processes, which makes them hazardous air pollutants. Currently, air is the most convenient oxidant for proton exchange membrane fuel cells (PEMFCs), and air quality is an important consideration because airborne contaminants can negatively affect fuel cell performance. The effects of exposing the cathode of PEMFCs to benzene and naphthalene were investigated using a segmented cell system. The introduction of $2 \mathrm{ppm} \mathrm{C}_{6} \mathrm{H}_{6}$ resulted in moderate performance loss of $40-45 \mathrm{mV}$ at $0.2 \mathrm{~A} \mathrm{~cm}^{-2}$ and $100-110 \mathrm{mV}$ at $1.0 \mathrm{~A} \mathrm{~cm}^{-2}$ due to benzene adsorption on $\mathrm{Pt}$ and its subsequent electrooxidation to $\mathrm{CO}_{2}$ under operating conditions and cell voltages of $0.5-0.8 \mathrm{~V}$. In contrast, PEMFC poisoning by $\sim 2 \mathrm{ppm}$ of naphthalene led to a decrease in cell performance from 0.66 to $0.13 \mathrm{~V}$ at $1.0 \mathrm{~A} \mathrm{~cm}^{-2}$, which was caused by the strong adsorption of $\mathrm{C}_{10} \mathrm{H}_{8}$ onto $\mathrm{Pt}$ at cell voltages of $0.2-1.0 \mathrm{~V}$. Naphthalene desorption and hydrogenation only occurred at potentials below $0.2 \mathrm{~V}$. The PEMFCs' performance loss due to each contaminant was recoverable, and the obtained results demonstrated that the fuel cells' exposure to benzene and naphthalene should be limited to concentrations less than $2 \mathrm{ppm}$.
\end{abstract}

Key words: PEMFC; Pt cathode; Benzene; Naphthalene; Segmented cell; Spatial EIS

\section{Introduction}

Proton exchange membrane fuel cells (PEMFCs), as electrochemical replacements for internal combustion engines in portable, stationary and automotive power generation, have continued attracting research and development efforts due to recent successful commercialization attempts. However, technical challenges such as reliability, durability and sufficient performance under different environmental conditions still exist and are associated with fuel cell degradation. One significant factor contributing to fuel cell performance loss and failure is contamination caused by fuel, air or system impurities [1-4]. Currently, air is the most convenient and economic oxidant for PEMFC operation; at the same time, however, air quality remains a major concern due to the presence of different air pollutants, including nitrogen- and sulfur-containing compounds $\left(\mathrm{NO}_{\mathrm{x}}, \mathrm{NH}_{3}, \mathrm{SO}_{2}\right)$, volatile organic compounds, carbon monoxide and particulates. Airborne contaminants damage fuel cell performance mainly by affecting catalysts because platinum readily chemisorbs a large variety of inorganic and organic compounds, thereby

* Corresponding author:

E-mail address: tatyanar@hawaii.edu (T.V. Reshetenko) 
reducing the electrochemically active area (ECA) and altering sluggish oxygen reduction reaction (ORR) from a 4-electron to a 2-electron pathway [5]. Moreover, the contaminants and the products of electrochemical/chemical transformations may also affect membrane conductivity and the hydrophilic properties of gas diffusion layers (GDLs), resulting in performance loss due to an increase in ohmic and mass transfer overpotentials.

Extensive research efforts have been dedicated to examining PEMFC cathode contamination caused by inorganic pollutants such as $\mathrm{SO}_{2}[3,6-15], \mathrm{NO}_{x}[3,7,8,11,12,14-18], \mathrm{NH}_{3}[7,8,11$, $13,19,20], \mathrm{H}_{2} \mathrm{~S}[7,8,11,12,21]$ and $\mathrm{Cl}^{-}[13,22-26]$. However, studies on the effects of organic compounds such as air contaminants are smaller in scope and limited by benzene [15, 27, 28], 1,3-butadiene [28], toluene [29, 30] and chemical warfare agents [27]. Because organic compounds have the potential to decrease PEMFC performance, a list of 260 possible airborne contaminants provided by the Environmental Protection Agency has been evaluated. Several contaminants have been selected for further detailed studies of their effects on fuel cells [31]. The chosen contaminants belong to different classes of organic substances: alkenes $\left(\mathrm{C}_{3} \mathrm{H}_{6}\right)$, alkynes $\left(\mathrm{C}_{2} \mathrm{H}_{2}\right)$, arenes $\left(\mathrm{C}_{6} \mathrm{H}_{6}, \mathrm{C}_{10} \mathrm{H}_{8}\right)$, alcohols $\left(\mathrm{i}-\mathrm{C}_{3} \mathrm{H}_{7} \mathrm{OH}\right)$, nitriles $\left(\mathrm{CH}_{3} \mathrm{CN}\right)$, esters $\left(\mathrm{CH}_{2}=\mathrm{C}\left(\mathrm{CH}_{3}\right) \mathrm{COOCH}_{3}\right)$ and alkyl halides $\left(\mathrm{CH}_{3} \mathrm{Br}\right)$. The selected compounds are widely used as chemical reagents, solvents, welding fuels and pesticides, and they cause negative effects on PEMFC performance [31-35]. According to our studies, these effects are accounted for different mechanisms of interaction between membrane electrode assembly (MEA) components and the contaminants, depending on their chemical nature and properties.

Aromatic compounds (benzene and naphthalene) are considered possible air pollutants because they are produced or used in many industrial processes. Benzene is a natural component of crude oil, with a concentration ranging from 0.001 to $0.4 \%$, and petroleum refineries are the primary source of $\mathrm{C}_{6} \mathrm{H}_{6}$. Other commercial sources of benzene include direct extraction from the light oil formed during coal coking and from gas-well condensates [36]. Benzene is predominantly used as a starting material for the chemical synthesis of ethylbenzene, cumene, cyclohexane and other substituted aromatic hydrocarbons. More than half of all benzene produced is processed into ethylbenzene, a precursor to styrene, which is used for manufacturing polymers and plastics. Benzene is also used as a gasoline additive (1-5\% by volume) to increase octane rating and reduce knocking. Other products that incorporate benzene include solvents and pesticides. Naphthalene is another significant arene and is commercially produced from coal tar or petroleum. Worldwide, naphthalene is mainly used for the manufacturing of phthalic anhydride by vapor-phase catalytic oxidation, a precursor for polyvinyl chloride plasticizers. Naphthalene is also used in the manufacture of a wide variety of intermediates for the dye industry, synthetic resin, surfactants, moth repellent and pesticides [37, 38].

Emission sources of benzene and naphthalene are similar and may be distinguished based on generation mechanism because they are emitted as products of the incomplete combustion of wood, straw, tobacco, fossil fuels (gasoline, diesel, oil, coal) and through evaporation or 
sublimation of $\mathrm{C}_{6} \mathrm{H}_{6^{-}}$and $\mathrm{C}_{10} \mathrm{H}_{8}$-containing materials such as coal tar, crude oil, petroleum products and moth repellent. Emissions can be also classified as natural sources (wildfires) and as anthropogenic sources, which are a much larger and more significant sources of exposure.

Benzene is emitted during its production and from coke ovens. The other major sources of benzene in air are motor vehicle exhaust and evaporation losses during handling, distribution and storage of gasoline. The benzene concentration in ambient air generally ranges from 1 to $30 \mu \mathrm{g} \mathrm{m}^{-3}(0.3 \mathrm{ppb}-0.01 \mathrm{ppm})$, depending on the proximity of traffic or industrial objects [39, 40]. The extensive use of naphthalene as an intermediate in the chemical industry and its presence as a major component of coal tar has led to its occurrence in industrial effluents, outdoor and indoor environments. In addition to these sources, the emission of naphthalene is similar to that of benzene and occurs through wood and stationary fossil fuel combustion and burning. Air concentrations of naphthalene in cities typically vary from 0.5 to $1.0 \mu \mathrm{g} \mathrm{m}^{-3}(0.1$ $0.2 \mathrm{ppb}$ ), whereas the maximum outdoor concentration can reach up to $5-25 \mu \mathrm{g} \mathrm{m}^{-3}$ (1-5 ppb) [37]. Tobacco smoking has been found to be a notable indoor benzene and naphthalene emission source, producing 90-500 $\mu \mathrm{g}$ benzene/cigarette and 15-18 $\mu \mathrm{g}$ naphthalene/cigarette [41].

The adsorption of benzene and its derivatives onto Pt has been a subject of fundamental studies due to considerable interest in various electrochemical syntheses involving aromatic hydrocarbons and for the purification of effluent from organic contaminants [42-51]. However, data concerning the effects of benzene and naphthalene on PEMFC performance and oxygen reduction are rare $[15,27,35]$. It was shown that even 2 ppm of $\mathrm{C}_{6} \mathrm{H}_{6}$ in air caused a fuel cell performance loss of $\sim 150 \mathrm{mV}$ at $1.0 \mathrm{~A} \mathrm{~cm}^{2}$ and $80^{\circ} \mathrm{C}$, whereas exposure to $2 \mathrm{ppm} \mathrm{C}_{10} \mathrm{H}_{8}$ resulted in a drastic decrease in cell voltage to $0.1 \mathrm{~V}$ under the same conditions. However, no explanation for the observed results was provided. Moreover, further detailed analysis and assessment are required because the evaluation of PEMFCs by single-cell testing usually provides only average values of current, voltage and impedance, whereas valuable information about local performance is beyond reach. In contrast, a segmented cell system provides spatially resolved voltage, current and impedance data and is a powerful tool for gaining a detailed understanding of fuel cell performance under various operating conditions, i.e., exposure to different fuel or air impurities [33, 34, 52-59]. The current work is a continuation of our previous studies regarding the effects of airborne pollutants on fuel cell performance and spatial PEMFC behavior under cathode exposure to benzene and naphthalene contaminants to assess relative transport processes along the flow field. The contaminant concentration used in this study was $2 \mathrm{ppm}$, which is higher than that observed under real conditions, to enhance and accelerate the effects of pollutants on fuel cells.

\section{Experimental}

The experiments were conducted on a GRandalytics single fuel cell test station using a segmented cell system [60]. This diagnostic tool was used in previous studies [61-64] and allows simultaneous measurements of spatial electrochemical impedance spectra (EIS), spatial linear 
sweep voltammetry (LSV) and cyclic voltammetry (CV) to be performed. The system has ten current channels in a high-current (standard) mode and ten channels in a low-current mode. The standard current mode enables the measurement of currents up to $15 \mathrm{~A}$ for each channel. The low-current mode allows for the measurement of currents as low as $375 \mathrm{~mA}$, which is typical for CV and LSV experiments.

The segmented cell hardware is based on a $100 \mathrm{~cm}^{2}$ cell design. The hardware contains a segmented flow field, which consists of ten cell segments forming a continuous path along ten parallel serpentine channels. Each segment has an area of $7.6 \mathrm{~cm}^{2}$ and its own distinct current collector and gas diffusion layer (GDL). The same channel designs are used for the segmented cathode and standard anode flow fields (the reactant streams are arranged in a co-flow configuration). The segmented cell hardware is applicable to either the anode or the cathode.

The segmented cell was operated with a commercially available $100 \mathrm{~cm}^{2}$ MEA provided by Gore. The anode and cathode were made of Pt/C catalysts with a loading of $0.4 \mathrm{mg}_{\mathrm{Pt}} \mathrm{cm}^{-2}$. Sigracet 25 BC was used for the anode and cathode GDLs. The cathode used a segmented GDL and gasket configuration, whereas a single GDL was applied at the anode, and the total active area of the MEA was $76 \mathrm{~cm}^{2}$. The gasket material was made of Teflon, with a thickness of $125 \mu \mathrm{m}$ for the anode and the cathode.

During benzene exposure in air, the dry contaminant gas was injected into a humidified air stream, which was maintained at a constant level by increasing the temperature setting of the humidifier unit. Naphthalene was supplied by sublimation of naphthalene powder using a temperature-adjustable portable oven $\left(\mathrm{T} \sim 30^{\circ} \mathrm{C}\right)$ and passing air $\left(\sim 40 \mathrm{ml} \mathrm{min}{ }^{-1}\right)$ through the oven. The anode/cathode testing conditions for the contamination experiments were $\mathrm{H}_{2} / \mathrm{air}$ in a $2 / 2$ stoichiometry, $100 / 50 \%$ relative humidity and $48.3 / 48.3 \mathrm{kPag}$ backpressure. The cell temperature was $80^{\circ} \mathrm{C}$. The MEA was operated under galvanostatic control of the whole cell current over the range of $0.1-1.6 \mathrm{~A} \mathrm{~cm}^{-2}$ (based on the $76 \mathrm{~cm}^{2}$ of the active MEA area).

The polarization curves (VI curves) in the $\mathrm{H}_{2}$ /air gas configuration were measured under the same conditions used in the contamination experiment. VI curve measurements were also performed in the $\mathrm{H}_{2} / \mathrm{He}+\mathrm{O}_{2}(21 \mathrm{vol} . \%)$ and $\mathrm{H}_{2} / \mathrm{O}_{2}$ gas configurations and under galvanostatic control of the total cell current. To maintain constant water transport in the cell for any given total cell current density, the flow rates of $\mathrm{H}_{2} / \mathrm{He}+\mathrm{O}_{2}$ and $\mathrm{H}_{2} / \mathrm{O}_{2}$ were identical to those used during the $\mathrm{H}_{2}$ /air operation with a stoichiometry of 2. Consequently, the stoichiometry of $\mathrm{He}+\mathrm{O}_{2}$ remained at 2, whereas the stoichiometry of $\mathrm{O}_{2}$ increased to 9.5. The resulting three different VI curves $\left(\mathrm{H}_{2} / \mathrm{air}, \mathrm{H}_{2} / \mathrm{He}+\mathrm{O}_{2}\right.$ and $\left.\mathrm{H}_{2} / \mathrm{O}_{2}\right)$ were used to determine the activation, ohmic and mass transfer (permeability and diffusion) overpotentials, as previously described [60].

The VI curve measurements and contamination experiments were combined with EIS to determine the high-frequency resistances (HFR) of the cell and segments and to record the 
impedance spectra for all ten segments and the overall cell. The selected frequency range for the EIS experiments was $0.05 \mathrm{~Hz}$ to $10000 \mathrm{~Hz}$, and the amplitude of the sinusoidal current signal perturbation was $2 \mathrm{~A}$, which resulted in a cell voltage amplitude of $10 \mathrm{mV}$ or lower. The HFR was determined from the intercept of the EIS with the x-axis at higher frequencies on the Nyquist plot.

CV experiments were conducted to determine the ECA using a Solartron SI 1287. The CV experiments were performed at a cell temperature of $35^{\circ} \mathrm{C}$ at a scan rate of $20 \mathrm{mV} \mathrm{s}{ }^{-1}$, while $100 \%$ humidified hydrogen and nitrogen were supplied to the reference/counter and working electrodes, respectively, at a flow rate of $0.7501 \mathrm{~min}^{-1}$. For each measurement, three cycles were applied over a potential range from -0.015 to $1.1 \mathrm{~V}$ vs. the reversible hydrogen electrode (RHE). The hydrogen desorption peak area of the third cycle was used to determine the ECA. Hydrogen crossover experiments were performed under the same temperature and flow conditions used in the ECA tests using an LSV from 0.1 to $0.4 \mathrm{~V}$ vs. the RHE at a scan rate of $0.1 \mathrm{mV} \mathrm{s}^{-1}$.

The segmented cell was assembled using established procedures, conditioned and subjected to a set of diagnostic tests. The beginning of test (BOT) diagnostics consisted of a CV to determine the ECAs of the electrodes, an LSV to determine the hydrogen crossover current of the cell and a measurement of the VI curves with spatial EIS using the $\mathrm{H}_{2} /$ air, $\mathrm{H}_{2} / \mathrm{He}_{2} \mathrm{O}_{2}$ and $\mathrm{H}_{2} / \mathrm{O}_{2}$ gas configurations to determine the performance and overpotential distributions of the cell and impedance responses. The same diagnostic tests (end of test (EOT)) were repeated after benzene and naphthalene contamination.

\section{Results}

\subsection{Effects of benzene on spatial PEMFC performance}

Fig. 1 presents the segments' voltages and normalized current densities observed under benzene exposure at overall cell current densities of 0.2 and $1.0 \mathrm{~A} \mathrm{~cm}^{-2}$. The normalized current density is a ratio between the measured current density at any moment and the initial value which was determined during the pre-poisoning stage. For the first 16 hours, the cell was operated with pure air, resulting in average voltages of 0.8 and $0.67 \mathrm{~V}$ for the low and high currents, respectively. The initial current density distribution ranged from 0.16 to $0.23 \mathrm{~A} \mathrm{~cm}^{-2}$ for the outlet and inlet segments at an overall current density of $0.2 \mathrm{~A} \mathrm{~cm}^{-2}$. An increase in the operating current to $1.0 \mathrm{~A} \mathrm{~cm}^{-2}$ caused the current distribution to vary from 0.87 to $1.07 \mathrm{~A} \mathrm{~cm}^{-2}$. Injection of $2 \mathrm{ppm}$ benzene into the air stream led to a decrease in cell and segment voltage. At steady state, the voltage losses were 40-45 and $100-110 \mathrm{mV}$ at 0.2 and $1.0 \mathrm{~A} \mathrm{~cm}^{-2}$, respectively, in agreement with results published in a few other studies [15, 27]. The observed performance drop was accompanied by a current density redistribution, which likely depended on the operating current and revealed different behavior patterns. 
Benzene exposure at $0.2 \mathrm{~A} \mathrm{~cm}^{-2}$ led to the lowest current density values of the inlet segments 1 4, whereas the outlet segments 8-10 exhibited an increase in produced current (Fig. $1 \mathrm{~b}$ ). The current distribution varied from $-10-12 \%$ for segment 1 to $+12-15 \%$ for segment 10 . The observed decrease in the segments 1-4 performance likely occurred due to $\mathrm{C}_{6} \mathrm{H}_{6}$ adsorption on $\mathrm{Pt}$ and its further conversion at the inlet of MEA, keeping the rest of cathode area unpoisoned. Operation of the cell in the galvanostatic regime required production of a constant current from the entire cell, and because the current of the inlet segments decreased, an increase of 10-15\% in the current of segments 8-10 occurred. Similar current redistribution behavior was previously reported for $\mathrm{CO}$ poisoning of an anode and $\mathrm{C}_{2} \mathrm{H}_{2}$ contamination of a cathode $[33,57,58]$. The opposite trend in the local current redistribution was detected during $\mathrm{C}_{6} \mathrm{H}_{6}$ cathode exposure at $1.0 \mathrm{~A} \mathrm{~cm}^{-2}$ (Fig. $1 \mathrm{~d}$ ), which resembled the effect of $\mathrm{CH}_{3} \mathrm{CN}$ on spatial fuel cell performance [34]. The inlet segments increased performance by $7-8 \%$; at the same time, a decrease in the current densities for the outlet segments by $\sim 9 \%$ was detected. Benzene most likely affected the inlet part of the MEA; however, products or intermediates of its chemical/electrochemical conversion moved downstream with the produced water, accumulated and affected Pt surface and ORR at the outlet of MEA, resulting in the obtained localized performance.
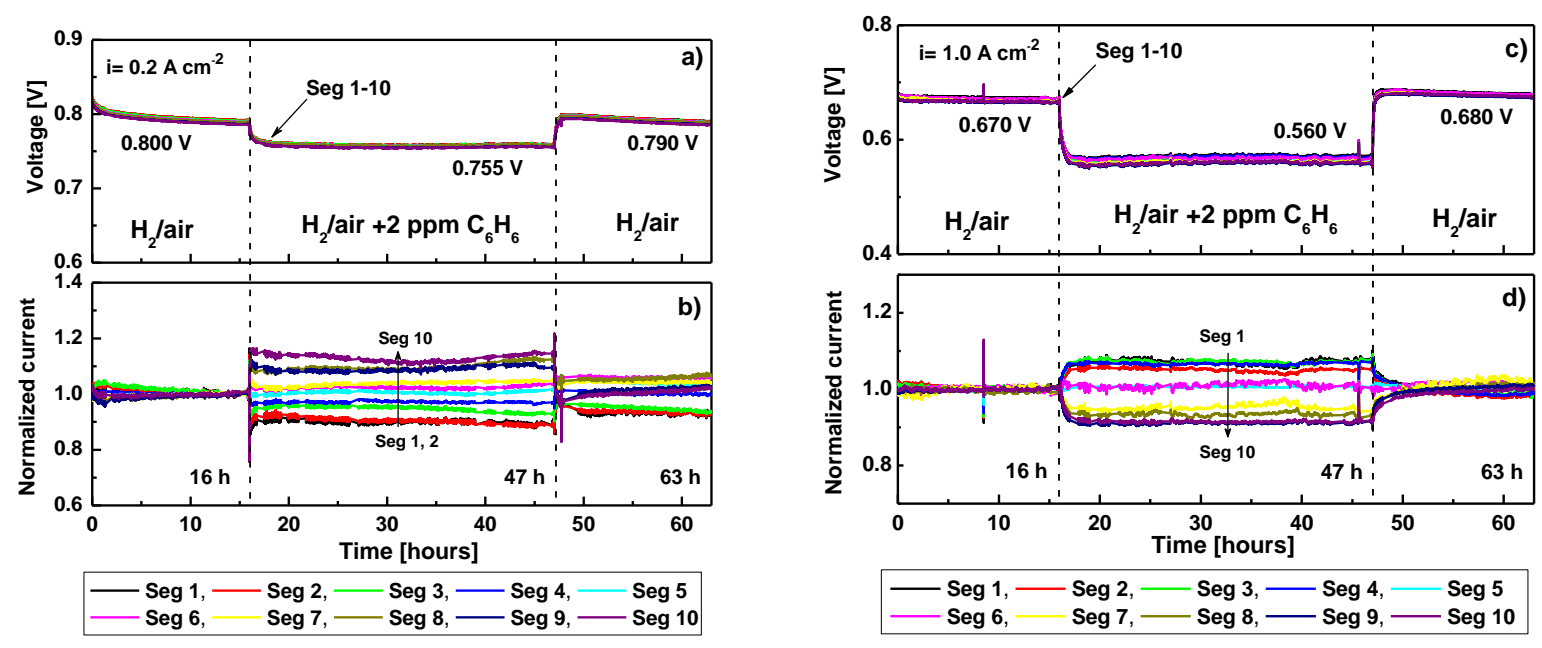

Fig. 1. Voltage and normalized current densities of segments under cathode exposure to 2 ppm of $\mathrm{C}_{6} \mathrm{H}_{6}$ for overall current densities of $0.2(\mathrm{a}, \mathrm{b})$ and $1.0 \mathrm{~A} \mathrm{~cm}^{-2}(\mathrm{c}, \mathrm{d})$. Anode/cathode: $\mathrm{H}_{2} /$ air, $2 / 2$ stoichiometry, $100 / 50 \% \mathrm{RH}, 48.3 / 48.3 \mathrm{kPag}, 80^{\circ} \mathrm{C}$.

The cell and segments almost restored their performance after stopping $\mathrm{C}_{6} \mathrm{H}_{6}$ injection at $0.2 \mathrm{~A} \mathrm{~cm}^{-2}$ (Fig. $1 \mathrm{a}$ ). The voltage reached $0.79 \mathrm{~V}$ vs. an initial value of $0.8 \mathrm{~V}$, however, the segment current densities did not recover completely after 16 hours of operation in pure air. A similar behavior was also found in previous work devoted to the study of $\mathrm{C}_{2} \mathrm{H}_{2}$ effects on a PEMFC [33]. There are at least two reasons that explain the incomplete recovery after $\mathrm{C}_{6} \mathrm{H}_{6}$ contamination: 1) presence of the contaminant or its residues on the Pt surface and 2) reversible catalyst degradation during long-term operation at a high voltage/low current density. Both processes are dependent on local operating conditions including relative humidity [34, 65, 66]. 
However, without additional information, it is not possible to determine the exact cause of the incomplete recovery in the presence of $\mathrm{C}_{6} \mathrm{H}_{6}$, especially because interactions between these 2 processes may exist. [67]. In contrast, operation at high current resulted in a full recovery of the cell when benzene exposure was stopped (Fig. $1 \mathrm{c}$ ). The cell voltage was $0.68 \mathrm{~V}$ vs. $0.67 \mathrm{~V}$, and normalized segment current densities were close to 1 (Fig. $1 \mathrm{c}$ ).
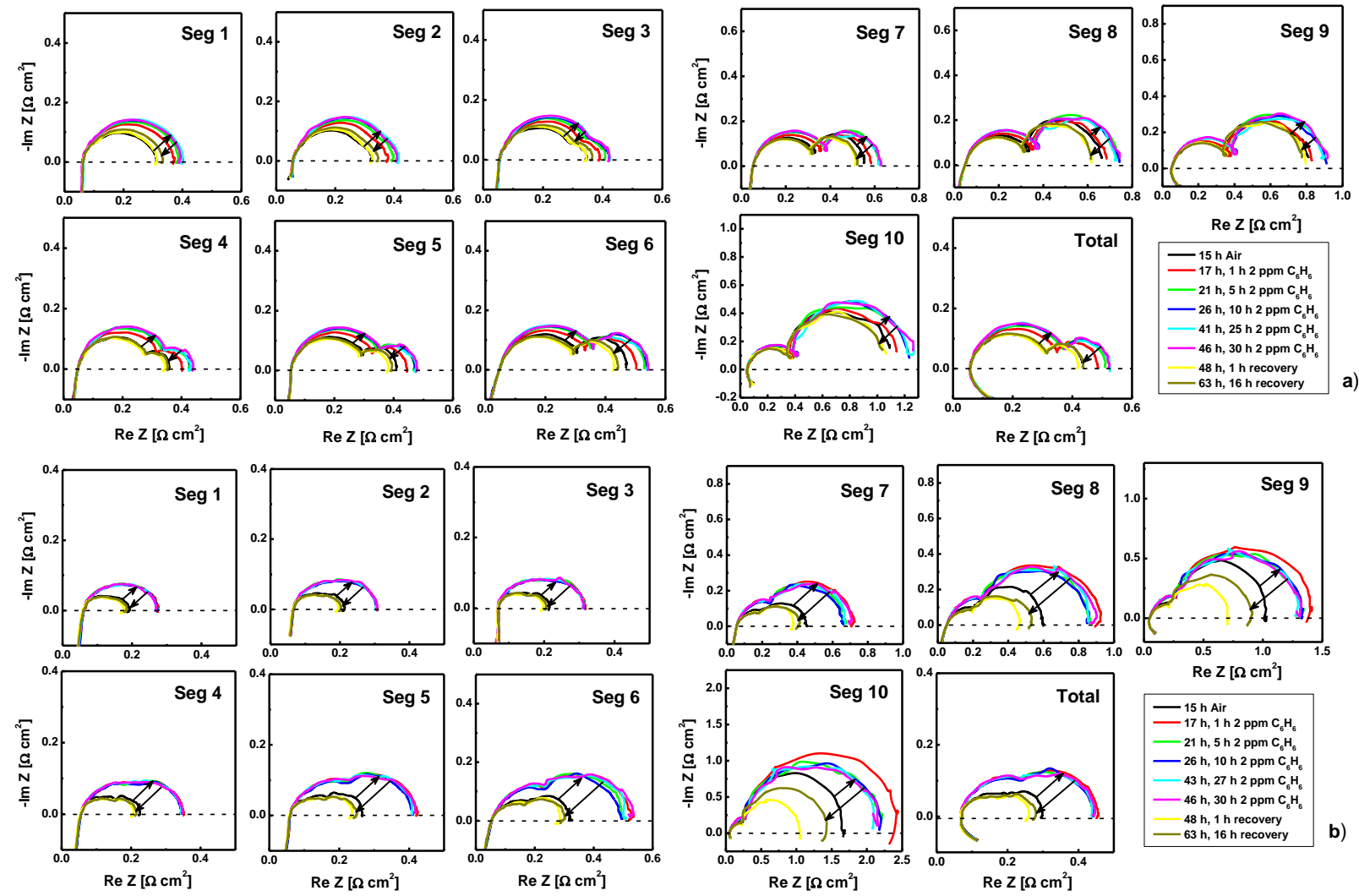

Fig. 2. EIS for segments 1-10 and the overall cell during $2 \mathrm{ppm}_{6} \mathrm{H}_{6}$ exposure test at 0.2 (a) and $1.0 \mathrm{~A} \mathrm{~cm}^{-2}$ (b). Anode/cathode: $\mathrm{H}_{2} /$ air, $2 / 2$ stoichiometry, $100 / 50 \% \mathrm{RH}, 48.3 / 48.3 \mathrm{kPag}, 80^{\circ} \mathrm{C}$.

Spatial EIS data for all ten segments and the overall cell during different stages of contamination are presented in Fig. $2 \mathrm{a}$ ) and b) for 0.2 and $1.0 \mathrm{~A} \mathrm{~cm}^{-2}$, respectively. The initial EIS spectra were recorded during the pre-poisoning stage after operation in pure air for 15 hours for both cases. The EIS curves of the fuel cell operated without any contaminants consisted of several arcs: a high-frequency arc, which can be distinguished at low-current operation; a high-frequency cathode loop due to charge transfer resistance and a double-layer capacitance of the ORR; and a low-frequency arc representing mass transfer limitations at the cathode, which is noticeable at high current. The diameter of the low-frequency mass transfer loop increased from the inlet to the outlet segments due to $\mathrm{O}_{2}$ depletion and water accumulation.

After 1 hour of benzene injection at $0.2 \mathrm{~A} \mathrm{~cm}^{-2}$, there was a slight increase in the cathode charge transfer and mass transfer resistances for all segments (Fig. 2 a). As $\mathrm{C}_{6} \mathrm{H}_{6}$ was continuously 
injected for 5 hours, the impedance continuously increased, and steady state was reached at 10 hours. A similar trend was observed for benzene exposure at $1.0 \mathrm{~A} \mathrm{~cm}^{-2}$ (Fig. $2 \mathrm{~b}$ ). Poisoning within 1 hour resulted in a pronounced increase in the cathode charge transfer and mass transfer resistances and the cell's steady-state operation. After 1 hour of operation in pure air during the recovery stage, a decrease in impedance was observed for all segments. Further recovery caused a slight variation in the spatial impedance responses.

The obtained results allowed us to conclude that even low concentrations of benzene in air (2 ppm) caused PEMFC performance losses of 40-45 and 100-110 mV depending on the operating current density due to its strong adsorption onto and interaction with Pt, which likely affected oxygen reduction and, consequently, the cell voltage. The performance drop was found to be recoverable, and the activity of the fuel cell was restored as soon as the injection of $\mathrm{C}_{6} \mathrm{H}_{6}$ was stopped.

\subsection{Effects of naphthalene on spatial PEMFC performance}

The spatial PEMFC performance under exposure to $2.3 \mathrm{ppm}$ naphthalene at an overall cell current density of $1.0 \mathrm{~A} \mathrm{~cm}^{-2}$ is illustrated in Fig. 3. For the first 17 hours, the cell was operated with pure air, resulting in a voltage of $0.662 \mathrm{~V}$. The initial current density redistribution varied over the range of $0.88-1.1 \mathrm{~A} \mathrm{~cm}^{-2}$ for the outlet and inlet segments due to oxygen depletion and water accumulation. The introduction of $2.3 \mathrm{ppm} \mathrm{C}_{10} \mathrm{H}_{8}$ into the air stream constantly decreased the cell voltage within 9 hours, resulting in a performance loss of $0.53 \mathrm{~V}$. The voltage profile revealed pronounced inflection points at $0.43-0.45 \mathrm{~V}$ and $0.26-0.28 \mathrm{~V}$ occurring after 3-3.5 and 5-5.5 hours of naphthalene poisoning, respectively. As soon as the cell reached $0.12-0.13 \mathrm{~V}$ voltage oscillations from 0.08 to $0.19 \mathrm{~V}$ was detected (Fig. $3 \mathrm{a}$ ). The naphthalene injection was stopped after observing the oscillations for 1 hour, mainly to prevent possible damage to the MEA. The load bank was equipped with a $5 \mathrm{~V}$ voltage booster to allow for operation down to $0 \mathrm{~V}$.

The local current underwent redistribution during naphthalene exposure, similarly to that observed during benzene poisoning at $1.0 \mathrm{~A} \mathrm{~cm}^{-2}$ (Fig. $1 \mathrm{~d}$ ). The current densities of inlet segments 1-6 increased immediately after the injection of $\mathrm{C}_{10} \mathrm{H}_{8}$ into the air stream, whereas the current densities of outlet segments 7-10 decreased (Fig. $3 \mathrm{~b}$ ). The current density profiles showed a well-distinguished extremum after 5 hours of contaminant exposure, which corresponded to the voltage inflection at $0.26-0.28 \mathrm{~V}$. The current density distribution at this

point varied from $+10-14 \%$ for the inlet segments to $-10 \%$ (segment 7 ) $-25 \%$ (segments 9 and $10)$.

The cell and segments recovered their performance within 2 hours after stopping $\mathrm{C}_{10} \mathrm{H}_{8}$ injection. The voltage reached $0.67 \mathrm{~V}$ vs. an initial value of $0.662 \mathrm{~V}$, and normalized individual current densities were close to 1 . However, the cell recovery involved a drastic local current 
redistribution, most likely due to naphthalene desorption and/or desorption of products of its chemical/electrochemical transformations. The maximum current was detected for segment 1 $(+39 \%)$, the segment 10 showed the minimum current density $(-39 \%)$.

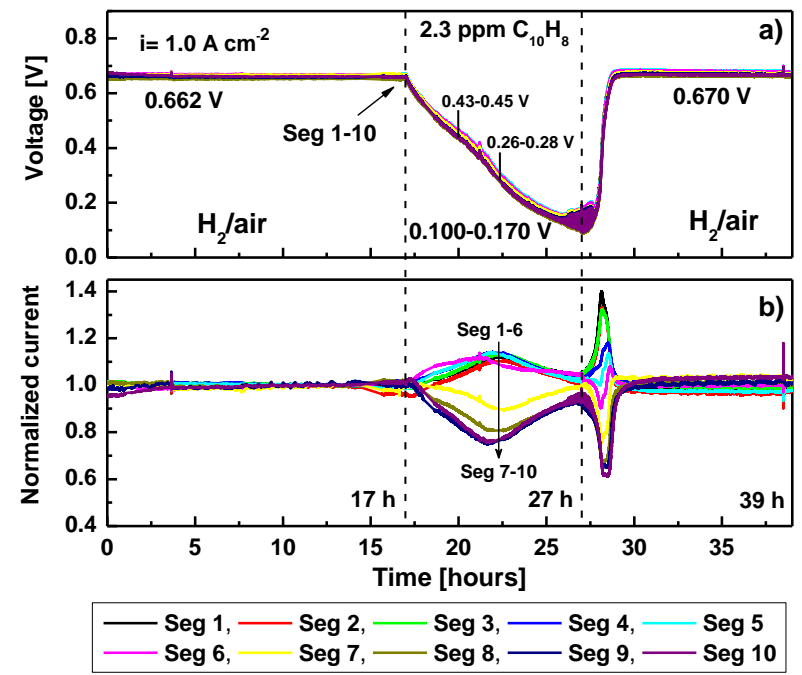

Fig. 3. Voltage (a) and normalized current densities (b) of segments under cathode exposure to $2.3 \mathrm{ppm}$ of $\mathrm{C}_{10} \mathrm{H}_{8}$ for an overall current density of $1.0 \mathrm{~A} \mathrm{~cm}^{-2}$. Anode/cathode: $\mathrm{H}_{2} /$ air, 2/2 stoichiometry, $100 / 50 \% \mathrm{RH}, 48.3 / 48.3 \mathrm{kPa}_{\mathrm{g}}, 80^{\circ} \mathrm{C}$.

Fig. 4 demonstrates the evolution of the spatial EIS behavior for the individual segments and whole cell under $\mathrm{C}_{10} \mathrm{H}_{8}$ poisoning. The initial EIS curves were recorded after 14 hours of operation with pure air. The introduction of naphthalene for 1 hour caused an increase in charge transfer resistance and mass transfer resistance. Further exposure of the cathode to the contaminant led to a continuous increase in the impedance responses for all segments and the appearance of low-frequency inductance for the segments 7-10. The low-frequency inductance was previously explained by the presence of two successive electron transfer steps involving the formation of an adsorbed intermediate species [68-72]. PEMFC exposed to air impurities $\left(\mathrm{C}_{2} \mathrm{H}_{2}\right.$, $\mathrm{CH}_{3} \mathrm{CN}$ and $\mathrm{CH}_{3} \mathrm{Br}$ ) also demonstrated a low-frequency inductance at potentials favoring the electroreduction of the contaminant, which occurred in parallel with oxygen reduction [33, 34]. Thus, the appearance of the inductive loop at low frequency suggests that there were sequential electrochemical reactions involving naphthalene, which interfered with oxygen reduction at the cathode and reduced the faradaic efficiency of the ORR. The operation with pure air in the recovery stage restored the performance of the segments and whole cell, in agreement with the voltage and current data obtained.

The PEMFC performance loss of $530 \mathrm{mV}$ under naphthalene exposure clearly demonstrates that $\mathrm{C}_{10} \mathrm{H}_{8}$ causes serious damage to an operating fuel cell presumably due to its strong adsorption onto Pt. The fuel cell performance was shown to be recoverable after 2 hours of operating in pure air. However, PEMFC exposure to naphthalene should be limited to concentrations much less 
than $2 \mathrm{ppm}$ to ensure stable operation.
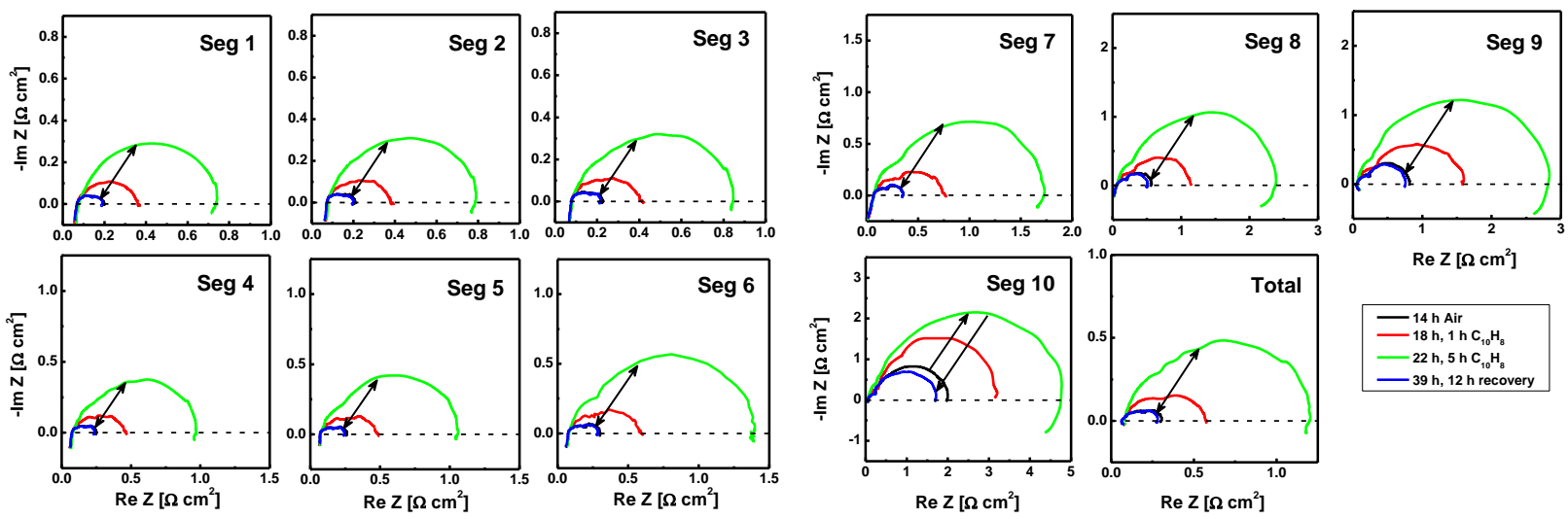

$\operatorname{Re} Z\left[\Omega \mathrm{cm}^{2}\right]$

$14 \mathrm{~h} \mathrm{Air}$
$-18 \mathrm{~h}, 1 \mathrm{~h} \mathrm{C} \mathrm{C}_{10}$ $-18 \mathrm{~h}, 1 \mathrm{~h} \mathrm{C}_{10} \mathrm{H}_{8}$
$-22 \mathrm{~h}, 5 \mathrm{~h} \mathrm{C} \mathrm{H}_{8}$ - $39 \mathrm{~h}, 12 \mathrm{~h}$ recovery

Fig. 4. EIS for segments $1-10$ and the overall cell during $2.3 \mathrm{ppm} \mathrm{C}_{10} \mathrm{H}_{8}$ exposure test at $1.0 \mathrm{~A} \mathrm{~cm}^{-2}$. Anode/cathode: $\mathrm{H}_{2} /$ air, $2 / 2$ stoichiometry, $100 / 50 \% \mathrm{RH}, 48.3 / 48.3 \mathrm{kPag}, 80^{\circ} \mathrm{C}$.

\subsection{Impacts of aromatic contaminants on PEMFC performance}

An analysis of the contamination tests and previous electrochemical studies on aromatic compounds on a Pt electrode [42-51] propose that PEMFC performance loss occurred mainly through the effects of benzene and naphthalene on Pt ECA and ORR. Deep catalytic oxidation of benzene and naphthalene over Pt containing catalysts occurs at temperatures higher than typical for fuel cell operation $\left(200-300^{\circ} \mathrm{C}\right)$, which makes chemical oxidation unlikely under PEMFC operating conditions [73].

It has been demonstrated that arenes are easily and non-dissociatively chemisorbed onto Pt electrodes, primarily in a "flat" orientation parallel to the surface, through the interaction of aromatic $\pi$-electrons with metal atoms [42, 44, 46, 74-76]. It has been shown that the electrosorption of benzene on Pt can be described by Frumkin [76, 77] or Temkin [46] isotherms, which consider the interactions between species adsorbed onto homogeneous surfaces and changes in adsorption energy with coverage, whereas adsorption kinetics follow the RoginskiiZel'dovich equation $[44,46]$.

The heat of adsorption of benzene and naphthalene on Pt (111) at $300 \mathrm{~K}$ was measured by singlecrystal adsorption calorimetry and found to decrease with coverage [78-80]. At low coverage, the adsorption energies for $\mathrm{C}_{6} \mathrm{H}_{6}$ and $\mathrm{C}_{10} \mathrm{H}_{8}$ were determined to be 114 and $330 \mathrm{~kJ} \mathrm{~mol}^{-1}$, respectively. Results also indicated that both benzene and naphthalene could be adsorbed onto the top of their chemisorbed molecules with heats of adsorption of $63-73$ and $83-87 \mathrm{~kJ} \mathrm{~mol}^{-1}$, respectively. Density functional theory calculations demonstrated that the best adsorption structure of benzene and naphthalene on $\mathrm{Pt}$ (111) is associated with aromatic rings on bridge sites with adsorption energies of $0.90 \mathrm{eV}\left(86.84 \mathrm{~kJ} \mathrm{~mol}^{-1}\right)$ and $1.37 \mathrm{eV}\left(132.18 \mathrm{~kJ} \mathrm{~mol}^{-1}\right)$, while hollow sites are less stable [81]. Similar results regarding $\mathrm{C}_{6} \mathrm{H}_{6}$ and $\mathrm{C}_{10} \mathrm{H}_{8}$ adsorption onto $\mathrm{Pt}$ 
(111) were reported in Ref. [82-84]. The preferred site for benzene at low coverage was reported to be the bridge site, with an adsorption energy of $117 \mathrm{~kJ} \mathrm{~mol}^{-1}$, at the same time adsorption onto hollow sites was characterized by an adsorption energy of $75 \mathrm{~kJ} \mathrm{~mol}^{-1}$ [82]. The bridge sites were determined to provide the best adsorbed naphthalene structures, with an adsorption energy of $34.9 \mathrm{kcal} \mathrm{mol}^{-1}\left(146.0 \mathrm{~kJ} \mathrm{~mol}^{-1}\right)$, whereas hollow sites ensured naphthalene adsorption with an adsorption energy of $10-11.8 \mathrm{kcal} \mathrm{mol}^{-1}\left(41.8-49.4 \mathrm{~kJ} \mathrm{~mol}^{-1}\right)$ [83]. Experimental and theoretical studies have clearly demonstrated that both arenes can be easily chemisorbed onto $\mathrm{Pt}$ not only as a monolayer but also as multilayer structures; moreover, the adsorption energy of $\mathrm{C}_{10} \mathrm{H}_{8}$ is higher than that of $\mathrm{C}_{6} \mathrm{H}_{6}$, which indicates a stronger effect of naphthalene on PEMFCs.

The electrochemistry of benzene and naphthalene on metal electrodes has been studied over the past several decades by CV, differential electrochemical mass spectroscopy (DEMS), FTIR and radiotracer methods [42-51, 76, 7777, 85-87]. The shape of CV curves on Pt electrodes is nearly identical for both contaminants, which block the Pt surface at hydrogen adsorption/desorption as well as in regions where platinum oxides form.

On polycrystalline Pt electrodes, benzene is oxidized to $\mathrm{CO}_{2}$ at potentials corresponding to the oxidation of the Pt surface (>0.8 V), with the formation of a well-resolved peak at $\sim 1.35 \mathrm{~V}$ [ 44 , 46-87]. However, oxidation occurs through several steps. In the first CV anodic scan, benzene can be oxidized to $\mathrm{CO}_{2}$ and form partially oxidized intermediates (likely benzoquinone), which stay adsorbed onto the Pt surface [48-51]. Lack of $\mathrm{C}_{6} \mathrm{H}_{6}$ desorption and higher $\mathrm{CO}_{2}$ formation at the beginning of the oxygen reduction region in the second $\mathrm{CV}$ cycle confirm that the remaining adsorbate consists of products of partial benzene oxidation, which can be further oxidized at potentials lower than those required to oxidize benzene itself [87]. The onset of $\mathrm{CO}_{2}$ evolution on polycrystalline $\mathrm{Pt}$ was found to be at $0.6 \mathrm{~V}$, which shows that for benzene oxidation the simultaneous adsorption and desorption of oxygen is required [87]. Oxygen adsorption and desorption activate the $\mathrm{C}-\mathrm{C}$ bonds in the adsorbed benzene by altering metal-metal distances, and therefore, oxidation can occur, since surface restructuring is considered to be a possible bondbreaking mechanism [88].

Benzene is desorbed in the potential region corresponding to hydrogen adsorption; the desorption starts at $0.15-0.2 \mathrm{~V}$ and is nearly complete at the negative potential limit [44, 46-86]. Benzene hydrogenation to cyclohexane is facilitated by low potentials; indeed, cyclohexane appears to be the main desorption product (80-90\%) [48, 49, 86]. Partially hydrogenated products, e.g., cyclohexene, were not detected in Ref. [86]; however, traces of cyclohexene were observed by J.L. Rodríquez [49].

Electrooxidation of naphthalene reveals one broad oxidation peak in the CV curve with a maximum at $1.35 \mathrm{~V}$, a behavior that is similar to benzene [51]. The oxidation occurs through partially oxidized intermediates and is completed within three cycles. Moreover, the number of oxidation charges per $\mathrm{CO}_{2}$ molecules is greater than theoretically expected (20-30\%), indicating 
that naphthalene oxidation does not lead solely to $\mathrm{CO}_{2}$ but also to other nonvolatile oxidation products [51]. Adsorbed naphthalene desorbs as naphthalene, tetralin and fully hydrogenated decalin in the hydrogen adsorption potential region. The desorption of naphthalene starts below $0.2 \mathrm{~V}$, the formation of tetralin is detected at $0.05 \mathrm{~V}$, and decalin formation is detected at potentials lower than $0 \mathrm{~V}$ [51].
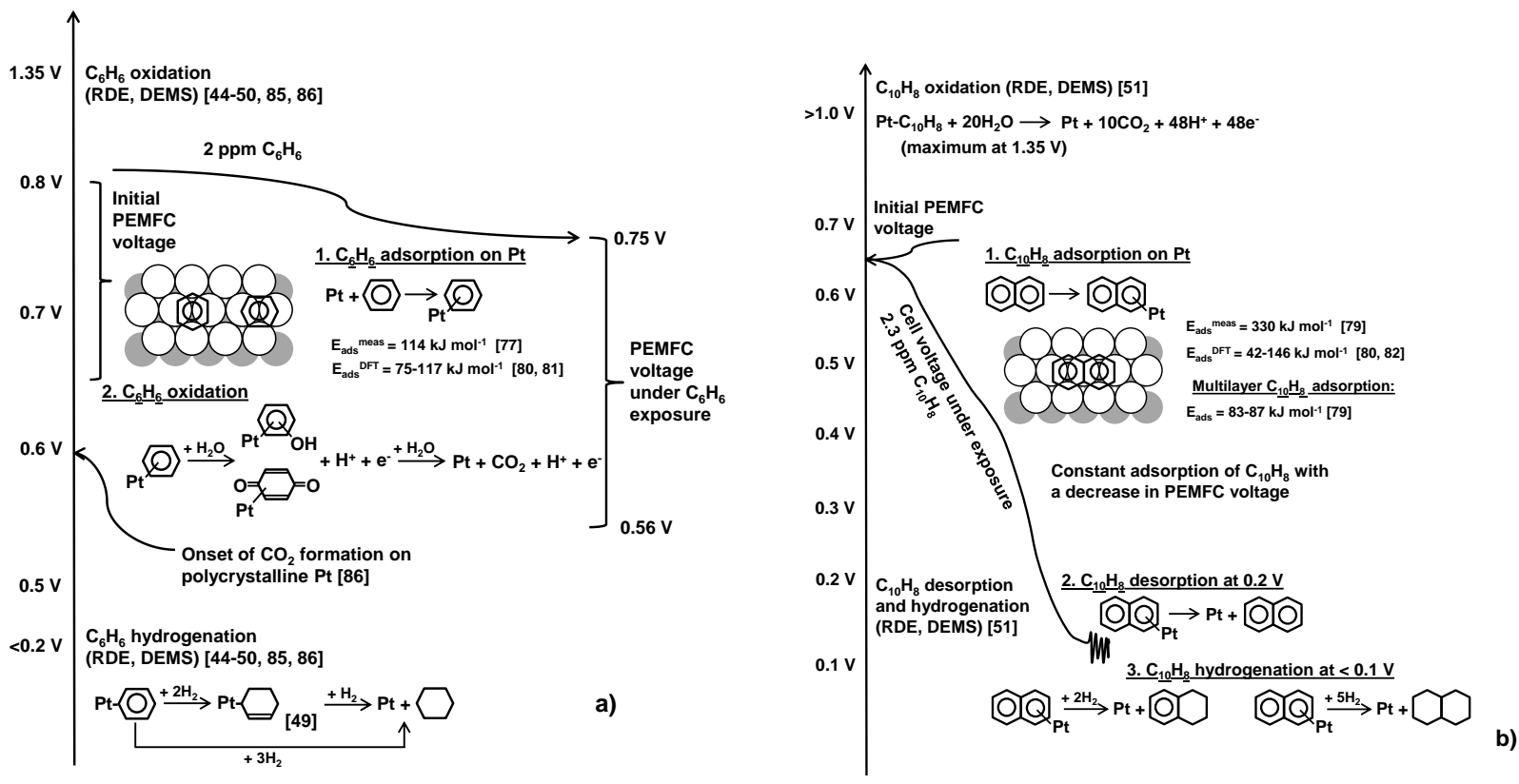

Fig. 5. Schematic of the possible chemical processes undergone by benzene (a) and naphthalene (b) during PEMFC operation.

The effects of the air pollutants on PEMFC can be described by the schemes presented in Fig. 5, which take into account the observed performance data and published results. At the beginning of contamination, benzene and naphthalene chemisorb onto the Pt surface, causing a decrease in Pt ECA and an inhibition of platinum oxide formation, which strongly affects oxygen reduction and the efficiency of fuel cell performance. Rotating disk electrode (RDE) studies confirm that poisoning of the Pt electrode by aromatic compounds leads to a cathodic shift in the ORR with the formation of $\mathrm{H}_{2} \mathrm{O}_{2}[5,30]$. Observations indicate changes in the oxygen reduction mechanism from a 4-electron to a 2-electron pathway due to modifications of the geometrical properties of catalyst particles (blockage of available surface area for proper $\mathrm{O}_{2}$ adsorption) and the redistribution of electronic density between the adsorbate and catalyst. All of these effects result in an initial local current redistribution, a decrease in cell voltage and an increase in EIS responses. However, subsequent transformations of benzene and naphthalene are different.

The oxidation of adsorbed $\mathrm{C}_{6} \mathrm{H}_{6}$ onto polycrystalline Pt was found to begin at voltages as low as $0.6 \mathrm{~V}$ [87], which suggests that oxidation occurs at low and high currents under fuel cell conditions (Fig. 5 a). Taking the HFR of the cell $\left(\sim 0.07 \mathrm{Ohm} \mathrm{cm}^{2}\right)$ into account and assuming 
that the anode potential is $\sim 0 \mathrm{~V}$, the cathode potentials under contaminant exposure (cell voltage compensated by the ohmic loss) is $\sim 0.77$ and $0.63 \mathrm{~V}$ for operation at 0.2 and $1.0 \mathrm{~A} \mathrm{~cm}^{-2}$, respectively. However, a comparison of the potentials reported at the DEMS and RDE with the observed PEMFC voltages is not quite appropriate because 1) the cell voltages must be converted to potentials vs. the standard hydrogen electrode instead of the RHE and 2) the potentials are reported mainly for aqueous media (acid or alkaline) and standard conditions (room temperature and ambient pressure). Benzene oxidation to $\mathrm{CO}_{2}$ proceeds through several steps [48-51]; however, the oxidation appears to be a fast process compared with the ORR because EIS did not reveal any low-frequency inductance or other features. The origin of the reverse order of local currents observed at 0.2 and $1.0 \mathrm{~A} \mathrm{~cm}^{-2}$ (Fig. $1 \mathrm{~b}$, d) is not clear, but it might be associated with an effect of partially oxidized benzene intermediates and explained by the fact that benzene electrooxidation requires the adsorption/desorption of oxygen on $\mathrm{Pt}[87$, 88], which is hindered at low cell voltage. The PEMFC voltage did not decrease below $0.5 \mathrm{~V}$ under the applied operating conditions; thus, hydrogenation of adsorbed benzene is not favorable at high potentials and does not take place.

Naphthalene oxidation begins at potentials higher than $1.0 \mathrm{~V}$, and its hydrogenation begins at potentials lower than $0.2 \mathrm{~V}$ [51] (Fig. 5 b). The adsorption of naphthalene is stronger than that of benzene because the measured heat of adsorption for the former is twice as high (330 vs. $114 \mathrm{~kJ} \mathrm{~mol}^{-1}$, respectively), and even multilayer adsorption is possible [78, 80]. Thus, only $\mathrm{C}_{10} \mathrm{H}_{8}$ adsorption on a $\mathrm{Pt}$ electrode can occur at PEMFC operating voltages $(0.8-0.4 \mathrm{~V})$, resulting in a continuous accumulation of naphthalene on the Pt surface, which decreases ORR efficiency/cell voltage and increases impedance. Similar PEMFC behavior was observed when $\mathrm{C}_{2} \mathrm{H}_{2}$ was studied as an air contaminant [33]. The observed inflection points at 0.43-0.45 and 0.26-28 V (Fig. 3 a) could be attributed to potential-dependent structural changes in the adsorbate layer and/or Pt surface. When the cell reaches voltages below $0.2 \mathrm{~V}$, the adsorbed naphthalene can desorb and be reduced to tetralin and decalin. Naphthalene electroreduction occurs in parallel with the ORR and competes with it for hydrogen/protons. The observed lowfrequency inductance in spatial EIS (Fig. 4) implies that naphthalene electrochemical reduction is likely slower than oxygen reduction under given operating conditions, which might be associated with voltage oscillations. Recovery of the fuel cell's activity requires nearly 2 hours and consists of two stages: continuous voltage oscillations over the range of $\sim 0.08-0.19 \mathrm{~V}$ for 50 55 minutes and a fast voltage increase from 0.18 to $0.67 \mathrm{~V}$ within 1 hour. The continuous desorption of naphthalene and its reduction could explain the oscillations upon recovery. As the Pt surface becomes free of $\mathrm{C}_{10} \mathrm{H}_{8}$ and its residues, the cell restores its initial performance during the second stage of recovery.

\subsection{Effects of $\mathrm{C}_{6} \mathrm{H}_{6}$ and $\mathrm{C}_{10} \mathrm{H}_{8}$ exposure on fuel cell performance and $\mathrm{ECA}$ after the recovery}

A comparison of initial ECA values for three MEAs examined revealed a slight variation in active areas (Table 1). The anode ECA was found to be in the range of 77-79 $\mathrm{m}^{2} \mathrm{~g}^{-1}$, whereas for 
the cathode, ECA varied from 74 to $81 \mathrm{~m}^{2} \mathrm{~g}^{-1}$. Nevertheless, the initial levels of performance of the samples were similar; for example, the cell voltage was $0.66-0.67 \mathrm{~V}$ at $1.0 \mathrm{~A} \mathrm{~cm}^{-2}$ (Fig. 1, 3). The distributions of the anode and cathode ECA differences are shown at Fig. 6. The ECA difference was calculated between the ECA measured after the contamination test (EOT) and before it (BOT). The fuel cell operation under contaminant exposure caused anode and cathode ECA losses of 1-5 and 11-16\%, respectively. It is clear that the anode ECA was more weakly affected than the cathode ECA. Typically, a decrease in the cathode ECA less than $20 \%$ does not lead to a noticeable increase in activation overpotentials or performance decline; therefore, the cell performances were not expected to be affected significantly.

Table 1. Electrochemical surface area of the samples before and after contamination tests.

\begin{tabular}{lcccccc}
\hline & \multicolumn{2}{c}{ Anode ECA $\left[\mathrm{m}^{2} \mathrm{~g}^{-1}\right]$} & \multicolumn{2}{c}{ Cathode ECA $\left[\mathrm{m}^{2} \mathrm{~g}^{-1}\right]$} & \multicolumn{2}{c}{$\Delta$ ECA [\%] } \\
\cline { 2 - 7 } & BOT & EOT & BOT & EOT & anode & cathode \\
\hline $\mathrm{C}_{6} \mathrm{H}_{6}, 0.2 \mathrm{~A} \mathrm{~cm}^{-2}$ & 78.74 & 75.04 & 74.57 & 64.22 & 4.3 & 13.9 \\
$\mathrm{C}_{6} \mathrm{H}_{6}, 1.0 \mathrm{~A} \mathrm{~cm}^{-2}$ & 78.81 & 77.94 & 74.82 & 66.29 & 1.1 & 11.4 \\
$\mathrm{C}_{10} \mathrm{H}_{8}, 1.0 \mathrm{~A} \mathrm{~cm}^{-2}$ & 77.44 & 73.69 & 80.68 & 68.19 & 4.8 & 15.5 \\
\hline
\end{tabular}
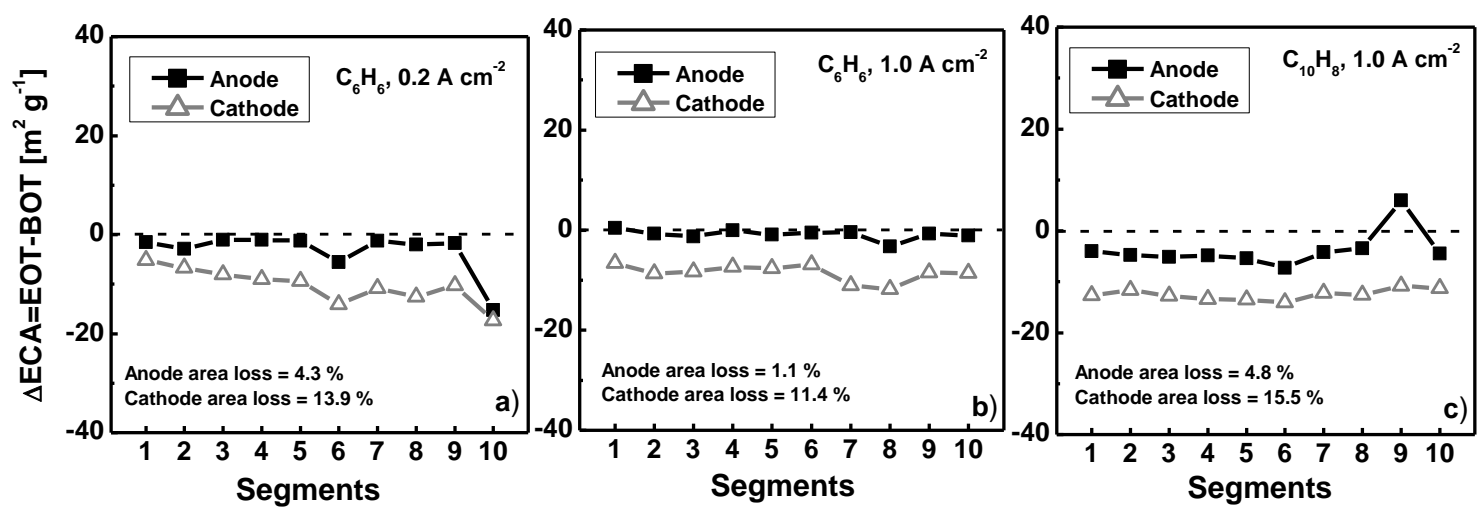

Fig. 6. Distributions of anode and cathode ECA differences between after (EOT) and before (BOT) exposure to aromatic contaminants: $\mathrm{C}_{6} \mathrm{H}_{6}$ at $0.2 \mathrm{~A} \mathrm{~cm}^{-2}$ (a), $\mathrm{C}_{6} \mathrm{H}_{6}$ at $1.0 \mathrm{~A} \mathrm{~cm}^{-2}$ (b) and $\mathrm{C}_{10} \mathrm{H}_{8}$ at $1.0 \mathrm{~A} \mathrm{~cm}^{-2}$ (c). Anode/cathode parameters for ECA measurements: $\mathrm{H}_{2} / \mathrm{N}_{2}$, $0.75 / 0.751 \mathrm{~min}^{-1}, 100 / 100 \% \mathrm{RH}, 35^{\circ} \mathrm{C}, 0 / 0 \mathrm{kPag}, 20 \mathrm{mV} \mathrm{s}{ }^{-1}$.

Spatial PEMFC performances before (BOT) and after the contamination tests (EOT) are compared in Fig. 7, which shows voltage distributions obtained from VI curves for each segment at fixed local current density. Benzene exposure at low and high current densities caused a slight variation over the range of $10 \mathrm{mV}$ for some segments (Fig. $7 \mathrm{a}, \mathrm{b}$ ). At the same time, naphthalene caused a slight decrease in performance $(\sim 10 \mathrm{mV})$ at the inlet of the MEA (segments 1-4) (Fig. 7 c). The localized BOT and EOT performances for both aromatic contaminants were 
analyzed in terms of activation, ohmic and mass transfer overpotentials, as described in the experimental section. The data reveal that the performance changes were due to variations in mass transfer losses. The observed performance discrepancies can be related to fuel cell degradation and contaminant effects, but it is difficult to quantitatively separate these two contributions. In fact, the variations in the BOT and EOT performances are small and suggest that exposure to aromatic compounds at a low concentration of $2 \mathrm{ppm}$ does not lead to serious effects on PEMFC performance after recovery.
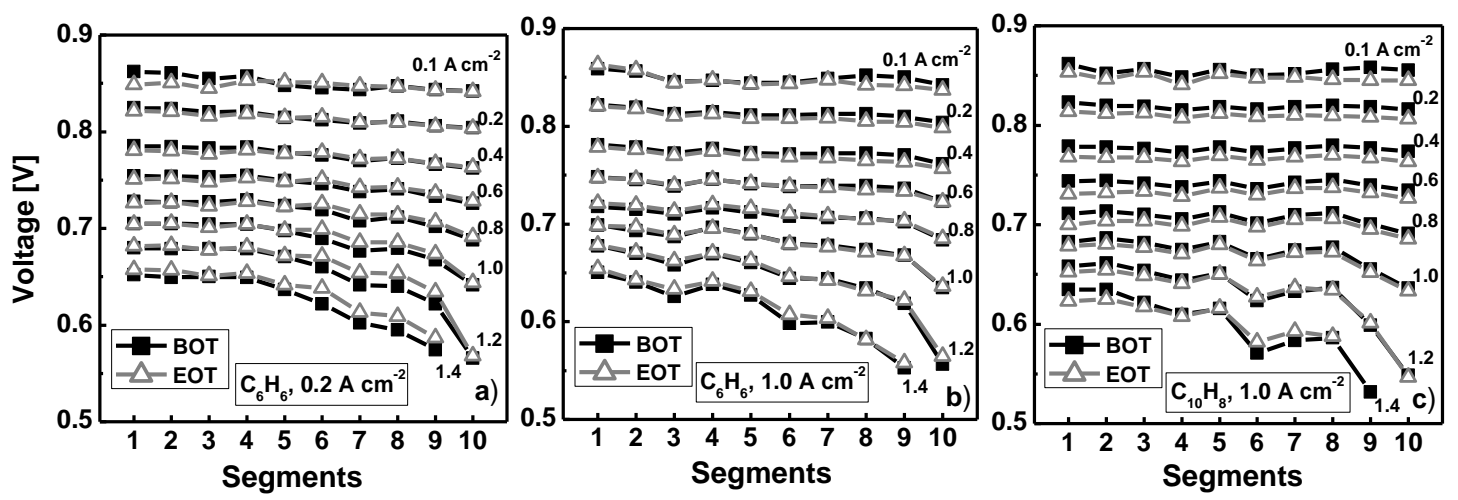

Fig. 7. Voltage distribution before (BOT) and after (EOT) 2 ppm $\mathrm{C}_{6} \mathrm{H}_{6}$ exposure test at 0.2 (a), $1.0 \mathrm{~A} \mathrm{~cm}^{-2}$ (b) and $2.3 \mathrm{ppm} \mathrm{C}_{10} \mathrm{H}_{8}$ exposure at $1.0 \mathrm{~A} \mathrm{~cm}^{-2}$ (c). Anode/cathode: $\mathrm{H}_{2} /$ air, 2/2 stoichiometry, $100 / 50 \% \mathrm{RH}, 48.3 / 48.3 \mathrm{kPag}, 80^{\circ} \mathrm{C}$.

\section{Conclusion}

The spatial performance of PEMFCs exposed to $2 \mathrm{ppm}$ of arene contaminants (benzene and naphthalene) was studied using a segmented cell system. The exposure of the cathode to the selected air pollutants caused a cell performance loss of 40-45 $\left(\mathrm{C}_{6} \mathrm{H}_{6}, 0.2 \mathrm{~A} \mathrm{~cm}^{-2}\right), 100-110$ $\left(\mathrm{C}_{6} \mathrm{H}_{6}, 1.0 \mathrm{~A} \mathrm{~cm}^{-2}\right)$ and $530 \mathrm{mV}\left(\mathrm{C}_{10} \mathrm{H}_{8}, 1.0 \mathrm{~A} \mathrm{~cm}^{-2}\right)$. The effect of benzene on the fuel cells was found to be moderate and is explained by the adsorption of $\mathrm{C}_{6} \mathrm{H}_{6}$ onto $\mathrm{Pt}$ and its subsequent electrooxidation to $\mathrm{CO}_{2}$ under the operating conditions and at cell voltages of $0.5-0.8 \mathrm{~V}$. PEMFC poisoning by naphthalene led to a drastic drop in cell performance, mainly due to strong and possibly multilayer adsorption of $\mathrm{C}_{10} \mathrm{H}_{8}$ onto $\mathrm{Pt}$ at cell voltages of 0.2-1.0 V. Naphthalene desorption and hydrogenation only occurred at potentials lower than $0.2 \mathrm{~V}$. The adsorption of aromatic compounds onto the Pt surface appeared to result in a decrease in Pt ECA and an inhibition of platinum oxide formation, which strongly affected oxygen reduction and the efficiency of fuel cell performance due to changes in the ORR mechanism from a 4-electron to 2a electron pathway. The PEMFC voltage loss was recoverable for both contaminants; however, it took 2 hours for the cell to restore its performance after naphthalene poisoning. The obtained results demonstrate that PEMFC exposure to benzene and naphthalene should be limited to concentrations less than $2 \mathrm{ppm}$. 


\section{Acknowledgement}

The authors gratefully acknowledge the Department of Energy (award DE-EE0000467) and the Office of Naval Research (award N00014-13-1-0463) for funding this work and the Hawaiian Electric Company for their ongoing support of the operations of the Hawaii Sustainable Energy Research Facility. The authors also thank Günter Randolf for valuable support regarding system operation.

\section{References}

[1] O.A. Baturina, Y. Garsany, B.D. Gould, K.E. Swider-Lyons, in: H. Wang, H. Li, X.-Z. Yuan (Eds.), PEM fuel cell failure mode analysis, CRC Press, 2011, pp. 199-241.

[2] H. Li, J. Zhang, Z. Shi, D. Song, J. Zhang, in: H. Li, S. Knights, Z. Shi, J.W. Van Zee, J. Zhang (Eds), Proton Exchange Membrane Fuel Cells. Contamination and mitigation strategies, CRC Press, 2010, pp. 85-114.

[3] F.H. Garzon, F.A. Uribe, Effects of contaminants of catalyst activity, in: W. Vielstich, H.A. Gasteiger, A. Lamm, H. Yokokawa (Eds.), Handbook of Fuel Cells - Fundamentals, Technology and Applications, vol. 5. Advances in electrocatalysis, materials, diagnostics and durability, John Wiley \& Sons, 2010.

[4] Md. Opu, G. Bender, C.S. Macomber, J.W. Van Zee, H.N. Dinh, Understanding the effects of PEMFC contamination from balance of plant assembly aids materials: in situ studies, J. Electrochem. Soc. 162 (2015) F1011.

[5] U.A. Paulus, T.J. Schmidt, H.A. Gasteiger, Poisons for the $\mathrm{O}_{2}$ reduction reaction, in: W. Vielstich, H.A. Gasteiger, A. Lamm, H. Yokokawa (Eds.), Handbook of Fuel Cells Fundamentals, Technology and Applications, vol. 5. Advances in electrocatalysis, materials, diagnostics and durability, John Wiley \& Sons, 2010.

[6] Y. Garsany, O.A. Baturina, K.E. Swider-Lyons, Impact of $\mathrm{SO}_{2}$ on the oxygen reduction reaction at Pt/Vulcan carbon electrocatalysts, J. Electrochem. Soc. 154 (2007) B670.

[7] Y. Nagahara, S. Sugawara, K. Shinohara, The impact of air contaminants on PEMFC performance, J. Power Sources 182 (2008) 422.

[8] D. Imamura, E. Yamaguchi, Effect of air contaminants on electrolyte degradation in PEMFC, ECS Trans. 25 (2009) 813.

[9] S. Tsushima, K. Kaneko, H. Morioka, S. Harai, Influence of $\mathrm{SO}_{2}$ concentration and relative humidity on electrode poisoning in PEMFC, J. Therm. Sci. Technol. 7 (2012) 619.

[10] M.M. Saleh, M.I. Awad, F. Kitamura, T. Ohsaka, Sulphur dioxide poisoning and recovery of Pt nanoparticles: Effect of particle size, Int. J. Electrochem. Sci. 7 (2012) 12004.

[11] S. Knights, N. Jia, C. Chuy, J. Zhang, Fuel cell reactant supply - effects of reactant contaminants, Fuel cell seminar 2005, November 14-18, 2005, Palm Spring, CA, USA, Extended abstracts, p. 121.

[12] R. Mohtadi, W.-K. Lee, J.W. Van Zee, Assessing durability of cathodes exposed to common air impurities, J. Power Sources 138 (2004) 216. 
[13] S. Imabayashi, Y. Kondo, R. Komori, A. Kawano, T. Ohsaka, Effects of atmospheric trace species on the oxygen reduction reaction on the production of $\mathrm{H}_{2} \mathrm{O}_{2}$, ECS Trans. 16 (2008) 925.

[14] F. Jing, M. Hou, W. Shi, J. Fu, H. Yu, P. Ming, B. Yi, The effect of ambient contamination on PEMFC performance, J. Power Sources 166 (2007) 172.

[15] M.S. Angelo, J. St-Pierre, The effect of common airborne impurities and mixtures on PEMFC performance and durability, ECS Trans. 64 (2014) 773.

[16] J. St-Pierre, N. Jia, R. Rahmani, PEMFC contamination model: Competitive adsorption demonstrated with $\mathrm{NO}_{2}$, J. Electrochem. Soc. 155 (2008) B315.

[17] M. Chen, Ch. Du, J. Zhang, P. Wang, T. Zhu, Effect, mechanism and recovery of $\mathrm{NO}_{\mathrm{x}}$ poisoning on oxygen reduction reaction at Pt/C catalysts, J. Power Sources 196 (2011) 620.

[18] A.A. Franco, B. Barthe, L. Rouillon, O. Lemaire, Mechanistic investigation of $\mathrm{NO}_{2}$ impact on ORR in PEM fuel cells: a coupled experimental and multi-scale modeling approach, ECS Trans. 25 (2009) 1595.

[19] T. Lopes, J. Chlistunoff, J.-M. Sansiñena, F.H. Garzon, Oxygen reduction reaction on $\mathrm{Pt} /$ carbon fuel cell catalyst in the presence of trace quantities of ammonium ions: An RRDE study, Int. J. Hydrogen Energy 37 (2012) 5202.

[20] X.-Z. Yuan, H. Li, Y. Yu, M. Jiang, W. Qian, S. Zhang, H. Wang, S. Wessel, T.T.H. Cheng, Diagnosis of contamination introduced by ammonia at the cathode in a PEMFC, Int. J. Hydrogen Energy 37 (2012) 12464.

[21] B.D. Gould, O.A. Baturina, K.E. Swider-Lyons, Deactivation of Pt/VC PEMFC cathodes by $\mathrm{SO}_{2}, \mathrm{H}_{2} \mathrm{~S}$ and COS, J. Power Sources 188 (2009) 89.

[22] D. Imamura, K.Ohno, Impact of $\mathrm{Na}^{+}$and $\mathrm{Cl}^{-}$on degradation of PEMFC, LRD25-49, Fuel Cell Seminar 2009, November 16-19, 2009, Palm Springs, CA, USA.

[23] M.S. Mikkola, T. Rockward, F.A. Uribe, B.S. Pivovar, The effect of $\mathrm{NaCl}$ in the cathode air stream on PEMFC performance, Fuel Cells 7 (2007) 153.

[24] O.A. Baturina, A. Epsteyn, P. Northrup, K. Swider-Lyons, Insights into PEMFC performance degradation from $\mathrm{HCl}$ in air, J. Electrochem. Soc. 168 (2011) B1198.

[25] K. Matsuoka, S. Sakamoto, K. Nakato, A. Hamada, Y. Itoh, Degradation of polymer electrolyte fuel cells under the existence of anion species, J. Power Sources 179 (2008) 560.

[26] H. Li, H. Wang, W. Qian, S. Zhang, S. Wessel, T.T.H. Cheng, J. Shen, S. Wu, Chloride contamination effects on proton exchange membrane fuel cell performance and stability, J. Power Sources 196 (2011) 6249.

[27] J.M. Moore, P.L. Adcock, J.B. Lakeman, G.O. Mepsted, The effects of battlefield contaminants on PEMFC performance, J. Power Sources 85 (2000) 254.

[28] G. Mepsted, Investigation of the effects of air contaminants of SPFC performance, ETSU F/02/00172REP, DTI/Pub URN 01/905, UK Department of Trade and Industry, UK, 2001.

[29] H. Li, J. Zhang, K. Fatih, Z. Wang, Y. Tang, Z. Shi, S. Wu, D. Song, J. Zhang, N. Jia, S. Wessel, R. Abouatallah, N. Joos, PEMFC contamination: Testing and diagnosis of tolueneinduced cathode degradation, J. Power Sources 185 (2008) 272. 
[30] M.S. El-Deab, F. Kitamura, T. Ohsaka, Poisoning effect of selected hydrocarbon impurities on the catalytic performance of $\mathrm{Pt} / \mathrm{C}$ catalysts towards the oxygen reduction reaction, J. Electrochem. Soc. 160 (2013) F651.

[31] J. St-Pierre, Y. Zhai, M. Angelo, Effect of selected airborne contaminants on PEMFC performance, J. Electrochem. Soc. 161 (2014) F280.

[32] J. St-Pierre, M. Virji, Cell performance distribution in a low-temperature proton exchange membrane fuel cell stack during propene contamination, J. Appl. Electrochem. 46 (2016) 169.

[33] T.V. Reshetenko, J. St-Pierre, Study of acetylene poisoning of Pt cathode on proton exchange membrane fuel cell spatial performance using a segmented cell system, J. Power Sources 287 (2015) 401.

[34] T.V. Reshetenko, J. St-Pierre, Study of acetonitrile poisoning of Pt cathode on proton exchange membrane fuel cell spatial performance using a segmented cell system, J. Power Sources 293 (2015) 929.

[35] Y. Zhai, J. St-Pierre, M. Angelo, The impact of operating conditions on the performance effect of selected airborne PEMFC contaminants, ECS Trans. 50 (2012) 635.

[36] D. Gilbert, M. Byrne, J. Harris, W. Steber, C. Woodruff, An exposure and risk assessment for benzene, 1982

[37] C. Jia, S. Batterman, A critical review of naphthalene sources and exposure relevant to indoor and outdoor air, Int. J. Environ. Res. Public Health 7 (2010) 2903.

[38] IARC monograph on the evaluation of carcinogenic risks to human, vol. 82, Some traditional herbal medicines, some mycotoxins, naphthalene and styrene, IARC Press, Lyon, France, 2002, pp. 367-436.

[39] D. Schwela, O. Zali, Urban traffic pollution, E\&FN Spon, London, New York, 1999, p. 42.

[40] WHO air quality guidelines for Europe, $2^{\text {nd }}$ edition, Ch. 5.2. Benzene, 2000, http://www.euro.who.int/en/health-topics/environment-and-health/airquality/publications/pre2009/who-air-quality-guidelines-for-europe,-2nd-edition,-2000-cdrom-version

[41] S.M. Charles, S.A. Batterman, C. Jia, Composition and emission of VOCs in main- and side-stream smoke of research cigarettes, Atmos. Environ. 41 (2007) 5371.

[42] J. O’M. Bockris, M. Green, D.A.J. Swinkels, Adsorption of naphthalene on solid metal electrodes, J. Electrochem. Soc. 111 (1964) 743.

[43] E. Gileadi, L. Duić, J. O’M. Bockris, A comparison of radiotracer and electrochemical methods for the measurement of the electrosorption of organic molecules, Electrochim. Acta 13 (1968) 1915.

[44] V. E. Kazarinov, A.N. Frumkin, E.A. Ponomarenko, V.N. Andreev, Adsorption of benzene, phenol and naphthalene on platinum, Soviet Electrochem. 11 (1975) 796.

[45] M.P. Soriaga, J.L. Stickney, A.T. Hubbard, Electrochemical oxidation of aromatic compounds adsorbed on platinum electrodes. The influence of molecular orientation, J. Electroanal. Chem. 144 (1983) 207. 
[46] Yu.B. Vasil'ev, Kh.A. Maksimov, L.T. Gorokhova, Role of the benzene ring in adsorption of aromatic compounds on a platinum electrode, Soviet Electrochem. 21 (1985) 168.

[47] S.A. Kuliev, Yu.B. Vasil'ev, V.S. Bagotskii, Effect of substituents on electrooxidation of aromatic compounds and on their interaction with the platinum electrode surface, Soviet Electrochem. 22 (1986) 706.

[48] T. Hartung, U. Schmiemann, I. Kamphausen, H. Baltruschat, Electrodesorption from singlecrystal electrodes: analysis by different electrochemical mass spectrometry, Anal. Chem. 63 (1991) 44.

[49] J.L. Rodríguez, E. Pastor, A comparative study on the adsorption of benzyl alcohol, toluene and benzene on platinum, Electrochim. Acta 45 (2000) 4279.

[50] F. Montilla, F. Huerta, E. Marallon, J.L. Vazquez, Electrochemical behavior of benzene on platinum electrodes, Electrochim. Acta 45 (2000) 4271.

[51] Th. Löffler, E. Drbalkova, P. Janderka, P. Königshoven, H. Baltruschat, Adsorption and desorption reactions of bicyclic aromatic compounds at polycrystalline and $\mathrm{Pt}(111)$ studied by DEMS, J. Electroanal. Chem. 550-551 (2003) 81.

[52] T. Murahashi, T. Mitsumoto, E. Nishiyama, Current distribution of a PEMFC under CO poisoning, ECS Trans. 25 (2009) 869.

[53] D.J.L. Brett, P. Aguiar, N.P. Brandon, A.R. Kucernak, Measurement and modeling of carbon monoxide poisoning distribution within a polymer electrolyte fuel cell, Int. J. Hydrogen Energy 32 (2007) 863.

[54] T. Tingelöf, L. Hedström, N. Holmström, P. Alvfors, G. Lindbergh, The influence of $\mathrm{CO}_{2}$, $\mathrm{CO}$ and air bleed on the current distribution of a polymer electrolyte fuel cell, Int. J. Hydrogen Energy 33 (2008) 2064.

[55] M. Boaventura, H. Sander, K.A. Friedrich, A. Mendes, The influence of CO on the current density distribution of high temperature polymer electrolyte membrane fuel cells, Electrochim. Acta 56 (2011) 9467.

[56] S. Kirsch, R. Hanke-Rauschenbach, B. Stein, R. Kraume, K. Sundmacher, The electrooxidation of $\mathrm{H}_{2}, \mathrm{CO}$ in a model PEN fuel cell: oscillations, chaos, pulses, J. Electrochem. Soc. 160 (2013) F436.

[57] T.V. Reshetenko, K. Bethune, R. Rocheleau, Spatial PEMFC performance under CO poisoning at a low concentration using a segmented cell system, J. Power Sources 218 (2012) 412.

[58] T.V. Reshetenko, K. Bethune, M.A. Rubio, R. Rocheleau, Study of low concentration CO poisoning of $\mathrm{Pt}$ anode in a proton exchange membrane fuel cell using spatial electrochemical impedance spectroscopy, J. Power Sources 269 (2014) 344.

[59] T. Reshetenko, A. Serov, K. Artyushkova, I. Matanovic, S. Stariha, P. Atanassov, Tolerance of non-platinum group metals cathodes proton exchange membrane fuel cells to air contaminants, J. Power Sources 324 (2016) 556.

[60] T.V. Reshetenko, G. Bender, K. Bethune, R. Rocheleau, Systematic study of back pressure and anode stoichiometry effects on spatial PEMFC performance distribution, Electrochim. Acta 56 (2011) 8700. 
[61] S. Cleghorn, C.R. Derouin, M.S. Wilson, S. Gottesfeld, A printed circuit board approach to measuring current distribution in a fuel cell, J. Appl. Electrochem. 28 (1998) 663.

[62] J. Stumper, S.A. Campbell, D.P. Wilkinson, M.C. Johnson, M. Davis, In-situ methods for the determination of current distributions in PEM fuel cells, Electrochim. Acta 43 (1998) 3773 .

[63] C. Wieser, A. Helmbold, E. Gülzow, A new technique for two-dimensional current distribution measurements in electrochemical cells, J. Appl. Electrochem. 30 (2000) 803.

[64] G. Bender, M.S. Wilson, T.A. Zawodzinski, Further refinements in the segmented cell approach o diagnosing performance in polymer electrolyte fuel cells, J. Power Sources 123 (2003) 163.

[65] T.V. Reshetenko, G. Bender, K. Bethune, R. Rocheleau, Systematic study of the gas humidification effects on spatial PEMFC performance distribution, Electrochim. Acta 69 (2012) 220.

[66] R. L. Borup, J. R. Davey, F. H. Garzon, D. L. Wood, M. A. Inbody, PEM fuel cell electrocatalyst durability measurements, J. Power Sources 163 (2006) 76.

[67] L. Zhu, X. Li, X. Feng, X. Li, X. Xu, Synthesis and characterization of mesoporous graphite carbon, and adsorption performance for benzene, J Porous Mater 23 (2016) 957.

[68] R.D. Harington, M. Henderson, Impedance plane display of a reaction with an adsorbed intermediate, J. Electroanal. Chem. 39 (1972) 81.

[69] D.A. Harrington, B.E. Conway, AC impedance of faradaic reactions involving electrosorbed intermediates - I. Kinetic theory, Electrochim. Acta 32 (1987) 1703.

[70] Chu-Nan Cao, On the impedance plane displays for irreversible electrode reactions based on the stability conditions of the steady-state. I. One state variable besides electrode potential, Electrochim. Acta 35 (1990) 831.

[71] J.-P. Diard, B. Le Gorrec, C. Montella, Calculation, simulation and interpretation of electrochemical impedances. Part 3. Conditions for observation of low frequency inductive diagrams for a two-step electron transfer reaction with an adsorbed intermediate species, J. Electroanal. Chem. 326 (1992) 13.

[72] P. Córdoba-Torres, M. Keddam, R.P. Nogueira, On the intrinsic electrochemical nature of the inductance in EIS. A Monte Carlo simulation of the two-consecutive-step mechanism: The flat surface 2 D case, Electrochim. Acta 54 (2008) 518.

[73] D. Duprez, F. Cavani, Handbook of advanced methods and processes in oxidation catalysis: from laboratory to industry, Imperial College Press, London, 2014.

[74] M.P. Soriaga, A.T. Hubbard, Determination of the orientation of adsorbed molecules at solid liquid interfaces by thin-layer electrochemistry: Aromatic compounds at platinum electrodes, J. Am. Chem. Soc. 104 (1982) 2735.

[75] M.-C. Tsai, E.L. Muetterties, Platinum metal surface chemistry of benzene and toluene, J. Am. Chem. Soc. 104 (1982) 2534.

[76] M.A. Quiroz, F. Cordova, L. Salgado, M. Viniegra, Y. Meas, G. Díaz, The Frumkin model applied to the adsorption process of benzene on a Pt electrode from sulfuric acid solutions, Rev. Mex. Fis. 3 (1995) 386. 
[77] W. Heiland, E. Gileadi, J.O'M. Bockris, Kinetic and Thermodynamic aspects of the electrosorption of benzene on platinum electrodes, J. Phys. Chem. 70 (1966) 1207.

[78] H. Ihm, H.M. Ajo, J.M. Gottfried, P. Bera, C.T. Campbell, Calorimetric measurement of the heat of adsorption of benzene on Pt (111), J. Phys. Chem. B 108 (2004) 14627.

[79] O. Lytken, W. Lew, C.T. Campbell, Catalytic reaction energetics by single crystal adsorption calorimetry: hydrocarbons on Pt (111), Chem. Soc. Rev. 37 (2008) 2172.

[80] J.M. Gottfried, E.K. Vestergaard, P. Bera, C.T. Campbell, Heat od adsorption of naphthalene on Pt (111) measured by adsorption calorimetry, J. Phys. Chem. B 110 (2006) 17539.

[81] C. Morin, D. Simon, P. Sautet, Trends in the chemisorption of aromatic molecules on a Pt (111) surface: benzene, naphthalene, and anthracene from first principles calculations, J. Phys. Chem. B 108 (2004) 12087.

[82] M. Sayes, M.-F. Reyniers, G.B. Marin, Density functional study of benzene adsorption on Pt (111), J. Phys. Chem. B 106 (2002) 7489.

[83] G. Santarossa, M. Iannuzi, A. Vargas, A. Baiker, Adsorption of naphthalene and quinolone on Pt, Pd and Rh: A DFT study, Chem. Phys. Chem. 9 (2008) 401.

[84] S.J. Jenkins, Aromatic adsorption on metals via first-principles density functional theory, Proc. R. Soc. A 465 (2009) 2949.

[85] H. Dahms, M. Green, The Adsorption od aromatic hydrocarbons at the gold electrolyte interface, J. Electrochem. Soc. 110 (1963) 1075.

[86] T. Hartung, H. Baltruschat, Differential electrochemical mass spectroscopy using smooth electrodes: Adsorption and H/D-exchange reactions of benzene on Pt, Langmuir 6 (1990) 953.

[87] U. Schmiemann, Z. Jusys, H. Baltruschat, The electrochemical stability of model inhibitors: A DEMS study of adsorbed benzene, aniline and pyridine on mono- and polycrystalline Pt, Rh and Pd electrodes, Electrochim. Acta 39 (1994) 561.

[88] G.A. Somorjai, M.A. Van Hove, Surface restructuring as a mechanism for bond breaking and catalytic reactions at metal surfaces, Catalysis Letters 1 (1988) 433. 